\title{
Innovative development of the fuel and energy complex in the eastern regions of Russia
}

\author{
Alexander Sokolov ${ }^{1, *}$, Svetlana Muzychuk ${ }^{1}$, and Roman Muzychuk ${ }^{1}$ \\ ${ }^{1}$ Melentiev Energy Systems Institute of Siberian Branch of Russian Academy of Sciences, Irkutsk, Russia
}

\begin{abstract}
The most important direction of the current stage of Russia's development is the growth of its energy efficiency associated with the transition to innovative energy. The use of innovative technologies is an important factor influencing long-term forecasts of economic development and the fuel and energy complex (FEC), which necessitates the development of new approaches to justify the forecasts of the FEC development in Russia and its regions. Innovative development of the FEC will increase energy efficiency of the economy and improve the environment as fuel consumption will be reduced and emissions of harmful substances into the environment will be reduced. Solving this problem is important for Eastern regions, which are the most environmentally disadvantaged economic regions of Russia. This has determined the relevance of the study. The goal of the study is to determine the impact of innovative development of the fuel and energy complex on the economy of Eastern regions. Methods of research - system analysis, balance sheet, statistical methods. The authors developed a method to assess the impact of innovative development of the fuel and energy complex on the economy of the regions, created a model and computer tools.
\end{abstract}

Keywords. Fuel and energy complex, Eastern regions, innovation, economy, energy efficiency, best available technologies.

\section{Introduction}

Changes in the country's economy associated with the transition to intellectual energy make it necessary to develop new approaches to justify the forecasts of innovative development of the Russian fuel and energy complex and its regions. Application of innovative energy technologies leads to changes in the structure of supply and consumption of fuel and energy resources (FER). Such changes should be taken into account in the analysis and long-term forecasting of the innovative development of the FEC of Russia and its eastern regions. The use of innovation technologies has a great impact on such tasks as improving energy efficiency, increasing energy security, increasing competitiveness of the country and its regions, reducing environmental problems. Therefore, taking into account the possible use of innovative technologies becomes an important factor affecting longterm forecasts of economic and fuel and energy sector development.

Eastern regions have significant potential in application of innovations in the fuel and energy complex. Figure 1 shows the role of Eastern regions of Russia in FER production A large number of power generating enterprises for the development of fuel and energy industries on a new technological basis. Implementation of large investment projects for the renewal and modernization of production equipment. The presence of a large number of isolated from centralized energy for the use of advanced technological solutions in the creation of new power generating enterprises.

Efficiency of FER utilization is one of the important tasks in realization of national fuel and energy resources, interests of both the region and the country as a whole. Implementation of innovative development of the Fuel and Energy Complex, which promotes energy saving, will significantly improve energy efficiency of the economy and increase environmental safety of the eastern regions, since reduction of fuel consumption will significantly reduce harmful emissions into the environment.

In order to conduct research based on materials from foreign and Russian sources, an information and analytical base of innovative technologies in the FEC was created and a model and computer toolkit was developed to assess the impact of the innovative development of the fuel and energy complex in Eastern regions on the economy.

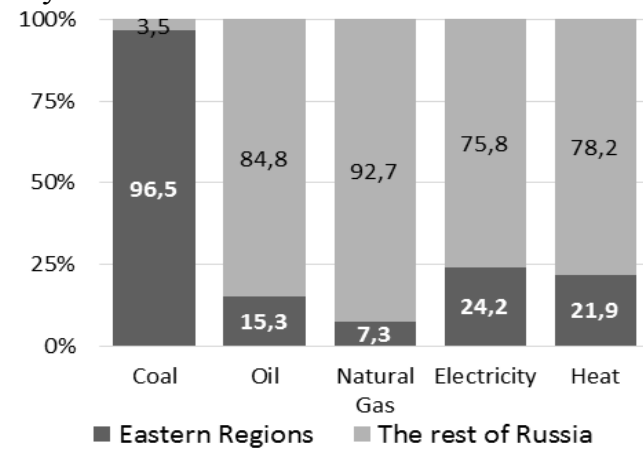

Fig. 1. The role of Eastern regions of Russia in FER production

\footnotetext{
* Corresponding author: sokolov@isem.irk.ru
} 


\section{Review of innovative energy technologies}

In the world one of the most authoritative organizations in the field of innovation development for the fuel and energy complex is the International Energy Agency (IEA), which helps to ensure uninterrupted and affordable energy supply to consumers in OECD member countries while preserving the environment [1]. The IEA has an Energy Technology Outlook project that introduces stakeholders to the world's promising energy technologies. The IEA has the following interests in the field of energy technologies: fossil fuel use, efficient final energy use, fusion, electric power industry. The main result of the project is the report "Prospects of energy technologies", which is published every two years. The Energy Technology Outlook 2017 report presents the results of a study of the impact of scientific and technological progress on the dynamics of the fuel and energy complex, on which energy and environmental security, as well as economic stability of OECD countries in the next decades will depend. According to the IEA, the introduction of innovative technologies in the power industry on a global scale will ensure annual fossil fuel savings of about 950-1100 million $t$ c. e. (which corresponds to the average annual consumption of natural fuel in Russia).

Japanese Business Alliance for Smart Energy Worldwide (JASE-W) is an organization established in 2008 to distribute Japan's advanced energy-saving developments. In "Japanese Smart Energy Products \& Technologies", released in 2017. [2], presents a large number of innovations (with a detailed description of their principle of operation and advantages over traditional technologies) that are used in various fields (including the fuel and energy sector) in Japan.

A few examples of innovations used in the Japanese electric power industry that can be successfully used in Russia.

1. A high performance thermal power plant with supercritical pressure. Steam turbines use the most optimal high-strength materials and designs suitable for high pressure and temperature conditions. In comparison with similar equipment (steam turbines of pre-critical pressure), this equipment has $5.5 \%$ and higher efficiency factor.

2. Thermal gas turbine unit is an energy system with total efficiency of more than $80 \%$ (Power generation efficiency - about $30 \%$, steam heat recovery efficiency - about $50 \%$ ) based on an electric generator turbine using natural gas as fuel with heat recovery of waste gases. This system is economical due to the lack of special high-voltage power supply systems from the power grid, energy-saving and environmentally friendly due to reduced $\mathrm{CO} 2$ emissions.

3. New generation of solar thermal power plants technology of molten salt parabolic trough (MSPT), the advantage of which (in comparison with other types of renewable energy sources) is convenience in energy storage and supply. Heliothermal energy can be stored in a reservoir and supplied to consumers regardless of the weather. The cost of energy storage is comparable to the cost of a battery. In the MSPT, synthetic oil is replaced by molten salt, which is used as a heat transfer fluid and can raise the operating temperature to $550^{\circ} \mathrm{C}$. Advantages of this system in comparison with the technology on synthetic oil: increased efficiency of steam turbines; convenience in energy storage; smaller size of the unit.

Japan is the world leader in thermal power plants that use coal as fuel (the highest efficiency among developed countries). Introduction of advanced high-efficiency Japanese technologies at coal-fired power plants, equipment replacement and a number of other innovations in Russia can give a great energy-saving effect: reduction of new power plant commissioning, reduction of coal and other fuel consumption.

Therefore, studying the experience of innovative technologies in developed countries is very important for Russia, which is developing its own domestic innovations in various areas (which is especially important under the conditions of ongoing anti-Russian sanctions and import substitution policy). The strategic task facing the Russian fuel and energy complex is the innovative development of its industries, which requires technological innovations.

At present, the innovative development in the Russian fuel and energy complex is being implemented in accordance with the policy documents developed by the Ministry of Energy of the Russian Federation: "Forecast of scientific and technological development of the Russian Fuel and Energy Complex sectors for the period up to 2035". (hereinafter referred to as STD Forecast); Road Map "Implementation of innovative technologies and modern materials in the fuel and energy sector"; Road Map "Energynet" of the National Technological Initiative; National Project "Intellectual Energy System of Russia".

The STD forecast lists the advanced technologies that can have the greatest effect on the development of the Russian economy. The most promising areas of development in the oil and gas sector include the introduction of technologies to increase oil recovery and oil recovery factor, development of hard-to-recover oil and offshore fields, LNG production and transportation [3]. The most promising innovations in the electric power industry include: "digitalization of power engineering" implementation of automated protection and control systems for power substations, development of technologies for active and adaptive power networks, technological concepts "SmartGrid" and "Energynet", introduction of new electrical, electromechanical and electronic equipment. In the coal industry, the most promising directions of technological development are considered to be: growth of technical level of coal mining by underground method and improvement of coal preparation technologies.

The STD forecast for the Russian Fuel and Energy Complex lists 24 main sectoral technologies, the introduction and diffusion of which can provide largescale economic effect, prevent threats to energy security and ensure technological independence of the country [3]. The largest number of these technologies (11) is in the oil and gas sector, of which three - in oil refining and oil and 
gas chemistry, ten innovative technologies are proposed for electric power industry and three - for coal industry.

The following innovative technologies are listed in the STD forecast for the development of Russia's oil and gas sector [3]: production of hard-to-recover and unconventional hydrocarbon reserves, including those offshore the Arctic and Far Eastern seas; hydraulic fracturing; drilling and construction of wells with complex profiles; production of coiled tubing for well intervention; enhanced oil recovery; integrated exploration of hydrocarbon deposits; production of catalysts for oil refining and petrochemical industries; and processing of hydrocarbons.

In the Russian electric power industry, according to the STD forecast, the following technologies are among the innovative ones [3]: production of large capacity gas turbine units (GTUs) with high efficiency; electrochemical, including fuel cells and accumulators of large capacity and capacity; environmentally friendly use of solid fuel in the power industry (include power units for super supercritical steam parameters, power units with coal combustion in a circulating fluidized bed; technologies of coal gasification with subsequent use of synthesis gas in a steam-gas cavity); technologies for gasification of coal.

The critical technologies proposed for the innovative development of the coal industry and listed in the STD forecast include: robotic coal mining technologies without permanent human presence in the working space; technologies for coal bed degassing and utilization of coal mine methane; coal preparation and deep processing [3]. Hydrogen energy, small distributed generation using renewable energy sources, photovoltaic converters, network drives are also included in the STD forecast [3]. In the framework of the National Technology Initiative (NTI), identified one of the important priorities of the state policy for the development of industries in the new technological mode and for the country's entry into the markets of the future, and has developed a roadmap "Energynet" [4], according to which it is planned to implement a number of technical pilot projects in the areas of increasing reliability and flexibility of power transmission networks for the development of intelligent distributed power generation and consumer services necessary for the implementation of solutions for active energy. The Russian Ministry of Energy is overseeing the implementation of the "Energynet" Road Map in terms of adjusting the regulatory framework, pilot technical projects, coordination of innovation policy within the power industry and at the level of power companies, and coordination of actions of all stakeholders.

The next policy document of the Ministry of Energy of the Russian Federation, according to which the innovative development of the electric power industry is currently being carried out, is the National Project "Intellectual Power System of Russia", the purpose of which is to create the necessary conditions for the transition to the intellectual power industry of the country through the formation of the relevant regulatory and normativetechnical base, including the improvement of the retail and wholesale electricity market, as well as through the creation of the necessary infrastructure and the creation of the necessary infrastructure [5].

\section{Innovative development scenario}

The information and analytical base of innovative technologies in the fuel and energy complex, designed for complex analysis and long-term forecasting of the innovative development of the fuel and energy complex of the eastern regions, was formed in accordance with the directives of the Ministry of Energy of the Russian Federation. It's most part was made up of the innovative technologies listed in the STD Forecast, and also takes into account a number of the most promising technological solutions and developments implemented in Russia and economically developed countries of the world. The forecast of innovative development of the fuel and energy complex of eastern regions should be based on the above mentioned technologies.

The innovative scenario of development of the FEC of Eastern regions is presented in Table 1.

Table 1. Innovation scenario indicators for the fuel and energy sector in Eastern regions of Russia

\begin{tabular}{|l|c|c|c|}
\hline \multicolumn{1}{|c|}{ Indicator } & $\mathbf{2 0 1 9}$ & $\begin{array}{c}\mathbf{2 0 2 6 -} \\
\mathbf{2 0 3 0}\end{array}$ & $\begin{array}{c}\mathbf{2 0 3 1 -} \\
\mathbf{2 0 3 5}\end{array}$ \\
\hline $\begin{array}{l}\text { GRP energy capacity, } \\
\text { kg c.e./ thousand rubles }\end{array}$ & 14 & $\begin{array}{c}12,5- \\
13,7\end{array}$ & $\begin{array}{c}11,8- \\
12,4\end{array}$ \\
\hline \multicolumn{3}{|c|}{ FER production: } \\
\hline - coal, mln t & 423 & $450-480$ & $465-495$ \\
\hline - oil, mln t & 86 & $110-122$ & $117-126$ \\
\hline - natural gas, bln m ${ }^{3}$ & 54 & $100-115$ & $120-135$ \\
\hline - electricity, bln kWh & 275 & $318-335$ & $332-366$ \\
\hline - termal energy, mln Gcal & 278 & $273-283$ & $280-293$ \\
\hline \multicolumn{4}{|c|}{ FER consumption: } \\
\hline - coal, mln t & 123 & $134-135$ & $134-138$ \\
\hline $\begin{array}{l}\text { - oil \& petroleum products, } \\
\text { mln t c.e. }\end{array}$ & 45 & $55-59$ & $61-64$ \\
\hline - natural gas, bln $\mathrm{m}^{3}$ & 30 & $30-31$ & $30-32$ \\
\hline - electricity, bln kWh & 276 & $305-320$ & $320-350$ \\
\hline
\end{tabular}

The most significant factors affecting the energy efficiency of the economy of Eastern regions are as follows: reduction of specific FER costs for production, especially in the most energy-intensive economic activities (metallurgy, timber processing, petrochemicals, etc.); reduction of energy consumption in the public sector, housing and utilities sector, and among the population through more rational consumption of energy resources; reduction of FER losses during their extraction, processing, transportation; and reduction of specific FER costs for energy production.

Mechanisms for implementing technological factors to improve energy efficiency in the economy of Eastern regions in the fuel and energy sector are as follows:

- decommissioning morally and physically obsolete equipment with low parameters of coal-fired thermal power plants; accelerating technical re-equipment and reconstruction of existing thermal power plants based on environmentally friendly technologies; 
- commissioning of highly efficient power generating capacities with minimal fuel consumption for power and heat generation (e.g., mini-CHPs, heat pumps, modern modular gas-fired boiler houses, wood processing waste, wood pellets, etc.) for isolated consumers;

- implementing energy-saving technologies and innovative equipment in the oil and gas coal industry, as well as in the processes of fuel and energy supply and distribution;

- reduction of FER losses in the oil and gas complex: according to the requirements of the Russian legislation, oil companies need to bring the utilization of associated petroleum gas up to $95 \%$ by either reinjection or application of innovative technologies. For example, fuel cell heat units (with efficiency up to $85 \%$ in combined production of electricity and heat), heat units based on external combustion engines, etc., which use associated petroleum gas as fuel;

- heat loss reduction: timely control and monitoring of technical condition of heat networks, diagnostics, analysis, operative repair, application of new heat protection materials, composite pipes, more complete use of secondary heat energy resources (including heat recovery units, recuperators, etc.).

Mechanisms for implementing technological factors in non-energy sectors of economic activity are:

- implementing of innovative technological processes and energy-saving equipment that allow rational reduction of fuel and energy consumption. For example, for electrical equipment, the use of capacitor units and frequencycontrolled electric drives, which allow saving up to 30$50 \%$ of the energy consumed; in the housing and utilities sector, the use of "smart lighting systems" of automatic lighting control systems and energy-efficient lighting devices;

- systematic implementation of resource-saving measures in accordance with the regional energy saving program. In existing buildings - sealing and elimination of heat loss through windows, doors, ventilation communications; in buildings under construction - wall insulation, installation of modern double-glazed windows, energy-saving roofs, economical heating systems, etc.

\section{Conclusion}

In the course of the research the following results were obtained. The information-analytical base of innovative technologies for complex analysis and long-term forecasting of innovative development of the fuel and energy complex was developed. The review of foreign and Russian sources on the application of innovative technologies in the fuel and energy complex industries was carried out. The implementation of innovations in the eastern regions was monitored. The impact of innovative development of the fuel and energy complex on the economy was assessed.

The introduction of innovative technologies has a significant impact on energy efficiency in the economy of Eastern regions, increasing their competitiveness and reducing environmental problems. The article shows the main directions of innovation and technological development of the fuel and energy complex in the eastern regions, and gives an economic assessment of this process.

Innovative development of the fuel and energy complex will have a positive impact on the economy and the environment, which will improve the quality of life of the population of eastern regions of Russia.

The results will be used in further studies to forecast the innovative development of the fuel and energy complex of the country and its Eastern regions and to develop recommendations on the use of effective innovative technologies in energy supply schemes for the development of regional energy strategies.

The scientific developments can be used by federal and regional authorities and energy companies to implement innovative technologies in the energy sector for reliable and efficient energy supply to consumers.

The research was carried out within the framework of project AAAA-A17-117030310445-9.

\section{References}

1. Energy Technology Perspectives 2017. [Electronic resource].

URL: http://www.iea.org/etp2017/summary/ (circulation date 11.04.2017).

2. Japanese Smart Energy Products \& Technologies, 2017. [Electronic resource]. URL: https://www.jasew.eccj.or.jp/technologies-r/ (circulation date 11.04.2017).

3. Forecast of scientific and technological development of the Russian fuel and energy sector for the period up to 2035. [Electronic resource]. URL: https://minenergo.gov.ru/node/8914 (circulation date 15.09.2017).

4. "ENERGYNET Roadmap of the National Technology Initiative. [Electronic resource]. URL: https://minenergo.gov.ru/node/8916 (circulation date 15.09.2017).

5. National project "Intelligent Energy System of Russia". [Electronic resource]. URL: https://minenergo.gov.ru/node/8917 (circulation date 15.09.2017). 